\title{
Bringing the Vagueness Doctrine on Campus
}

Although students have traditionally paid little attention to university disciplinary codes, recent campus disturbances have given these codes unprecedented significance. ${ }^{1}$ Those subjected to disciplinary proceedings have charged, among other things, that the provisions which regulate their behavior are too vague to inform them of what they may and may not do. ${ }^{2}$ Arguing that a broadly-worded code of conduct is necessary to govern, university administrators, however, have refused to make their regulations more precise. ${ }^{3}$

Although the public university is an administrative agency of the state, ${ }^{4}$ it is more like a political subdivision than the state and federal

1. Sherry, Governance of the University: Rules, Rights, and Responsibilities, 54 Caur. L. REv. 23, 27 (1966).

2. See, e.g., Dunmar v. Ailes, 348 F.2d 51 (D.C. Cir. 1965); Speake v. Grantham, 317 F. Supp. 1253 (S.D. Miss. 1970); Siegel v. Regents of Univ. of Cal., 308 F. Supp. 832 (N.D. Calif. 1970); French v. Bashful, 303 F. Supp. 1333 (E.D. La. 1969); Soglin v. Kauffman, 295 F. Supp. 978 (W.D. Wis. 1968), aff'd, 418 F.2d 163 (7th Cir. 1969); Esteban v. Central MIo. State College, 290 F. Supp. 622 (W.D. Mos. 1968), aff'd, 415 F.2d 1077 (8th Cir. 1969), cert. denied, 398 U.S. 965 (1970); Buttny v. Smiley, 281 F. Supp. 280 (D. Colo. 1963); Jones v. State Bd. of Educ, 279 F. Supp. 190 (M.D. Tenn. 1968), af' 'd, 107 F.2d 834 (Oth Cir.), cert. granted, 396 U.S. 817 (1969), cert. dismissed, 397 U.S. 31 (1970); Goldbeng v. Regents of Univ. of Cal., 248 Cal. App. 2d 867, 57 Cal. Rptr. 463 (1967); Carr v. St. John's Univ., 34 Misc. 2d 319, 231 N.Y.S.2d 403 (Sup. Ct.), rev'd, 17 App. Div. 2d 632, 231 N.Y.S.2d 410 af'd mem., 12 N.Y.2d 802, 187 N.E.2d 18, 235 N.Y.S.2d 834 (1962).

In response to the rising number of student challenges to university disciplinary procecdings the Federal District Court for the Western District of Missouri met en bane to establish guidelines for deciding such cases. General Order on Judicial Standards of Procedure and Substance in Review of Student Discipline in Tax Supported Institutions of Figher Education, 45 F.R.D. 133 (W.D. Mo. 1968).

3. See, e.g., Soglin v. Kauffman, 418 F.2d 163, 167 (7th Cir. 1969). A recent survey of all accredited colleges in Ohio revealed widespread reliance on vague regulations. The results were as follows:

(a) Each responding institution has such a regulation; (b) many of the regulations are vague or provide no standard at all; ... (c) in the 805 disciplinary actions reported in 1966 and 1967 by the 20 responding institutions, 150 or $18.6 \%$ were taken pursuant to general conduct regulations by admission of those institutions.

Note, Uncertainty in College Disciplinary Regulations, 29 Oruo St. L.J. 1023, $1035-36$ (1968.)

4. See, e.g., Dixon v. Alabama State Bd. of Educ., 294 F.2d 150, 155 (5th Cir.), cert. denied, 368 U.S. 930 (1961); Pratz v. Iouisiana Polytechnic Institute, 316 F. Supp. 872, 876 (W.D. La. 1970), appeal filed, 39 U.S.L.W. 3322 (U.S. Jan. 26, 1971) (No. 1252); Brooks v. Auburn Univ., 296 F. Supp. 188, 197 (M.D. Ala. 1969), aff'd, 412 F.2d 1171 (5th Cir. 1969); Goldberg v. Regents of Univ. of Cal., 248 Cal. App. 2d 867, 874, 57 Cal. Rptr. 463, 468 (1967).

The point is made succinctly in Note, The Emerging Law of Student's Rights, 23 Ank.

L. REv. 619, 622-23 (1970):

A state school is unquestionably an arm of the state, performing a public function. exercising discretion committed to it by the legislature, and regulating citizens affected by its activities by means of combined governmental functions. By treating school problems as problems of administrative law, the courts an give direct recognition to the primary fact of life in the school environment-the presence of state power applied to a specified, ongoing task. 
regulatory agencies that readily come to mind as typical administrative bodies. Like a political subdivision, the state university is charged with the governance of a multi-faceted community. In discharging its various functions the university "owns or controls . . . residences, classrooms, laboratories, offices, meeting places, restaurants, gymnasiums and playing fields ... and [it] maintains its own police force, hospital [and] parking lots ...." As the individual utilizes each of these facilities and assumes different roles, a different series of regulations may govern his relationship to the university. But, although some of these regulations are relatively narrow in the scope of activities to which they refer, those that have been challenged in the courts are usually "very general catchall rule[s] of good conduct," " such as one prohibiting "Disrespect for University authority; [and] any other infractions of standards of conduct that require severe disciplinary action." ${ }^{8}$ Another typically broad rule stipulates that:

Students of the college are expected to conduct themselves as ladies and gentlemen both within the College and elsewhere. For student conduct which is outside the jurisdiction of the College, but which tends to discredit or injure the College, the President is authorized by the Board of Visitors to impose such penalty as he may deem appropriate, including expulsion from the College.

Such vaguely phrased rules purport to govern the individual in all his campus roles.

These rules also prescribe a variety of sanctions for their violation. Among the penalties at the disposal of college officials are disciplinary probation, loss of social privileges and fines. Since few students have taken the time and energy to contest legally the imposition of minor sanctions, ${ }^{10}$ the rules most often subjected to judicial review for vagute-

5. Note, Private Government on the Campus-Judicial Review of University Expulsions, 72 YALE L.J. 1362, 1386 (1963).

6. Soglin v. Kauffman, 295 F. Supp. 978, 988 (W.D. Wis. 1968), aff'd, 418 F.2d 163 (7th Cir. 1969).

7. Linde, Campus Law: Berkeley Viewed from Eugene, 54 CALIF. L. REv, 40, 63 (1966).

8. Jones v. State Bd. of Educ., 279 F. Supp. 190, 201 (M.D. Tenn. 1968), aff'd, 407 F.2d 834 (6th Gir.), cert. granted, 396 U.S. 817 (1969), cert. dismissed, 397 U.S. 31 (1970).

9. Esteban v. Central Mo. State College, 290 F. Supp. 622,626 n.4 (W.D. Mo. 1968), aff'd, 415 F.2d 1077 (8th Cir. 1969), cert. denied, 398 U.S. 965 (1970).

10. Wright, The Constitution on the Campus, 22 VAND, L. REv, 1027, 1070 (1969). Exceptional cases are Siegel v. Regents of Univ. of Cal., 308 F. Supp. 832 (N.D. Calif. 1970) (student placed on probation for a one-year period, permitting him the privileges of a student, but prohibiting him from holding student government office or engaging in other extracurricular activities) and Perlman v. Shasta Joint Junior College Dist. Bd. of Trustecs, 9 Cal. App. 3d 873, 88 Cal. Rptr. 563 (1970) (student received a three-day suspension, which did not deny him the right to take examinations, and was placed on probation for the next term). Because courts are more reluctant to review the imposition of mild sanctions, students may fail to seek such review. On the range of lesser penaltics available to 
ness are those that have authorized suspension or the so-called "academic death penalty," expulsion. ${ }^{11}$

In the rising volume of cases in which they confront the problem of unclear student rules, ${ }^{12}$ the courts, apparently adopting the universities' viewpoint, have been reluctant to require precision in the regulations that define the scope of student freedom. ${ }^{13}$ Whether they permit universities to punish students without any rule at all, ${ }^{14}$ whether they require rules but reject the constitutional requirement of precision as "inapposite" to them, ${ }^{15}$ or whether they simply lower standards of precision so that they may be easily met, ${ }^{10}$ the courts have, with one notable exception, ${ }^{17}$ effectively kept the vagueness doctrine off campus.

university officials, see Esteban v. Central Afo. State Collegc, 290 F. Supp. 622, 629 (WVD. Mo. 1968), aff'd, 415 F.2d 1077 (8th Cir. 1969), cert. denicd, 398 U.S. 965 (1970); Van Alstync, The Student as University Resident, 45 DENVER L.J. 582, 606.08 (1968); Van Alstync, The Judicial Trend Toward Student Academic Freedom, 20 U. FLA. L. REv. 290, 297 (1963).

11. Van Alstyne, The Student as University Resident, 45 DENver L.J. 582,606 (1968). See also Carrington, Civilizing University Discipline, 69 MIrar. L. REv. 393, 398-99 (1971).

12. General Order on Judicial Standards of Procedure and Substance in Revien of Stu. dent Discipline in Tax Supported Institutions of Higher Education, 45 F.R.D. 133, 135 (W.D. Mo. 1968); Scoggin v. Lincoln Univ., 291 F. Supp. 161, 176 (W.D. Alo. 196S); Note, The Emerging Law of Students' Rights, 23 ARk. L. REv. 619 (1970).

13. See cases cited, supra note 2 (except Soglin v. Kaufman, 295 F. Supp. 978 (W.D. Wis. 1968), aff'd, 418 F.2d 163 (7th Cir. 1969)).

14. According to Buttny v. Smiley, 281 F. Supp. 280, 280 (D. Colo. 1969), "The right of University administration to invoke its disciplinary powers need not be entirely bottomed on any published rule or regulation." See also Norton v. Discipline Comm. of E. Tenn. State Univ., 419 F.2d 195, 200 (6th Cir. 1969), cert. denied, 399 U.S. 906 (1970). But c/. Grossner v. Trustees of Columbia Univ., 287 F. Supp. 535, 552 n.25 (S.D.N.Y. 1968).

15. Jones v. State Bd. of Educ., 279 F. Supp. 190, $201-02$ (Mf.D. Tenn. 1968), aff 4,407 F.2d 894 (6th Cir.), cert. granted, 396 U.S. 817 (1969), cert. dismissed, 397 U.S. 31 (1970).

16. This lowering of standards is reflected in the easy assumption of the court in Esteban v. Central Mo. State College, 415 F.2d 1077, 1088 (8th Cir. 1969), cert. denied, 393 U.S. $965(1970)$, that students possess sufficient intelligence to understand virtually any campus rule:

$\because$ [W]e do not find the regulation at all difficult to understand and we are positive the college student, who is appropriately expected to possess some minimum in. telligence, would not find it difficult ... . W We must assume [plaintifrs] an read and that they possess some power of comprehension.

See also Speake v. Grantham, 317 F. Supp. 1253, 1271 (S.D. Mfiss. 1970). Even Judge Doylc, while invalidating a University of Wisconsin regulation as unconstitutionally vague, suggested:

Nor is it necessary or wise presently to decide whether the standards of ragueness and overbreadth are to be applied as stringently to university regulations of conduct as to criminal statutes in non-university life.

Soglin v. Kauffman, 295 F. Supp. 978, 991 (W.D. Wis. 1968). The court also suggested that different levels of precision might be appropriate in rules governing different aspects of campus life. Id. at 991. In affrming, the Seventh Circuit emphzsized that its opinion did not purport to resolve the latter issue. $418 \mathrm{~F} .2 \mathrm{~d} \mathrm{163,167-68}$ (7th Cir. 1969). Since it is im. possible to generalize from such opinions concerning the degree of precision required of university rules, one cannot determine whether a decision adverse to student claims stems from repudiation of the vagueness doctrine on campus or merely a lowering of the degree of precision required.

17. Soglin v. Kauffman, 418 F.2d 163, 167 (7th Cir. 1969), af'g 295 F. Supp. 978 (W.D. Wis. 1968). 
A typical case is Esteban v. Central Missouri State College. ${ }^{18}$ Plaintiff left his dormitory to observe, at a distance of a hundred feet, the dispersal of a mass student demonstration in which, according to the court, he was at no time an active participant. Esteban initially ignored a faculty member's request that he return to his room. He subsequently complied but not before questioning the instructor's authority and the existence of any rule imposing a curfew. The instructor followed Esteban into the building and obtained his name from the resident assistant of the dormitory. In anger, Esteban swore at the informer and emptied a waste can at his feet. For "conduct unbefitting a student," Esteban was suspended from college. ${ }^{19}$ Both the district court and the court of appeals refused to apply the constitutional requirement of precision to university misconduct regulations. In so doing, the Esteban opinions accurately reflect what has become the standard judicial response to vagueness attacks on campus rules..$^{20}$

On several occasions where First Amendment freedoms were directly involved courts have in fact invalidated a campus regulation for uncertainty of meaning. Not only has a series of speaker bans been held unconstitutionally vague, ${ }^{21}$ but so have rules restricting student freedom to assemble, ${ }^{22}$ to establish political organizations, ${ }^{23}$ and to determine

18. Esteban v. Central Mo. State College, 290 F. Supp. 622 (W.D. Mo. 1968), aff'd, 115 F.2d 1077 (8th Cir. 1969), cert. denied, 398 U.S. 965 (1970).

19. The operative provision read in full:

Ail students are expected to conform to ordinary and accepted social customs and to conduct themselves at all times and in all places in a manner befitting a student of Central Missouri State College. . . . Conduct unbefitting a student which reflects adversely upon himself or the institution will result in disciplinary action.

Id. at 626 n.4.

20. See note 13 supra.

21. Pickings v. Bruce, 430 F.2d 595 (8th Cir. 1970); Stacy v. Williams, 306 F. Supp. 968

(N.D. Miss. 1969) ("charged with crimes"); Smith v. University of Tenn., 300 F. Supp. 777

(E.D. Tenn. 1969) ("competence" of speaker, "libelous, scurrilous or defamatory"); Brooks v. Auburn Univ., 296 F. Supp. 188 (M.D. Ala), aff'd, 412 F.2d 1171 (5th Cir. 1969) ("convicted"); Snyder v. Board of Trustees of Univ. of Ill., 286 F. Supp. 927 (N.D. Ill. 1968) ("sub. versive, seditious and un-American'); Dickson v. Sitterson, 280 F. Supp. 486 (M.D.N.C. 1968) ("Communist or subversive"); Dunbar v. Governing Bd. of Grossmont Junior Collcge Dist., 275 Cal. App. 2d 14, 79 Cal. Rptr. 662 (1969); Buckley v. Meng, 35 Misc. 2d 467, 230 N.Y.S.2d 924 (Sup. Ct. 1962) (regulation requiring program "to be compatible with the aims of Hunter College" before accorded use of facilities). But cf. Licberman v. Marshall, 236 So. 2d 120 (Fla. 1970) (university order restraining student groups, not recognized by university, from using university facilities for rally, held a valid limitation on first amend. ment rights).

22. Sword v. Fox, 317 F. Supp. 1055 (W.D. Va. 1970) (state college requirement that demonstrations be registered with office of student activities 48 hours in advance held unconstitutional suppression of spontaneous expression, and regulations prohibiting indoor demonstrations of any kind held unconstitutionally vague absent a showing that only such a total ban could prevent disruption).

23. ACLU of Virginia v. Radford College, 315 F. Supp. 893, 898 (W.D. Va. 1970) (A.C.L.U. members granted declaratory relief that under the First Amendment thcy were entitled to recognition as a state college campus chapter); Healy v. James, 311 F. Supp. 1275,1280 (D. Conn. 1970) (state college cannot constitutionally regulate the recognition of campus political organizations under vague standards). 
the editorial content of campus newspapers. ${ }^{24}$ The emphasis in these opinions on elements of free speech, however, seems to set them apart from non-First Amendment cases and to suggest that a court which declines to acknowledge the presence of important First Amendment rights can readily avoid applying the vagueness doctrine.

This limitation of the vagueness doctrine to First Amendment cases seems an inadequate response to the problems of uncertainty in campus regulations. This Note will seek to show the presumptive applicability of the vagueness doctrine to university rules generally, to demonstrate the special need for requiring precision on campus, and to confront the judicial arguments against that requirement. Finally, the Note will consider some implications of adopting the doctrine in the university setting.

\section{The Case for Precise Rules on Campus}

\section{A. The Purpose of the Vagueness Doctrine}

The "vagueness doctrine" is a well-established constitutional principle which has met with considerable judicial favor in other contexts. ${ }^{25}$ Its requirement that standards of conduct imposed by the government be reasonably precise stems from several due process goals derived from the Fifth and the Fourteenth Amendments. ${ }^{20}$ First, precision in terms affords the individual adequate warning ${ }^{27}$ - "fair notice"- that sanc-

24. Antonelli v. Hammond, 308 F. Supp. 1329, 1333 (D. Mass. 1970) (requirement that students submit newspaper articles to administrators prior to publiation held unconstitutional, since no guidelines of acceptability were established to limit administrative discretion); Dickey v. Alabama State Bd. of Educ., 273 F. Supp. 613 (MC.D. Als. 1967) (rulc precluding editorial criticism of state governor or legislator held unconstitutional); Hammond v. South Carolina State College, 272 F. Supp. 947 (D. S.C. 1967) (rule prohibiting "parades, celebrations, and demonstrations" without prior approval of college authorities held invalid as a prior restraint on First Amendment rights); Egan v. Mloore, $20 \mathrm{App}$. Div. 2d 150, 245 N.Y.S.2d 622 (1963), affd, 14 N.Y.2d 775, 199 N.E.2d 842, 250 N.Y.S.Md 809 (1969) (injunction against Communist's lecture at state university reversed in absence of showing that he would advocate forcible overthrow of the gorernment as any more than an abstract doctrine).

25. For general discussions of the vagueness doctrine, see Aigler, Legislation in Fague or General Terms, 21 MICH. L. REv. 831 (1923); Collings, Unconstitutional UncertaintyAn Appraisal, 40 Cornem L.Q. 195 (1955); Note, Due Process Requirements of Definileness in Statutes, 62 HARv. L. Rev. 77 (1948); Note, Void for Vagueness: An Escape from Statutory Interpretation, 23 IND. L.J. 272 (1948); Note, The Void-For-Vagueness Doctrine in the Supreme Court, 109 U. PA. L. REv. 67 (1960); Comment, Legislation-Requirement of Definiteness in Statutory Standards, 53 Mick. L. REv. 264 (1954). In the particular context of the university, see Note, 48 N. GAR. L. REv. 943 (1970); Note, Uncerlainty in College Disciplinary Regulations, 29 Ono ST. L.J. 1023 (1968).

26. The requirement of precision, first formulated as a component of due process under the Fifth Amendment, has been made applicable to the states through the Fourteenth Amendment. Comment, Legislation-Requirement of Definiteness in Statutory Standards, 53 MICH. L. REv. 264, 267 (1954).

27. In university regulations, as in other enactments, adequate notice would apprise students not only that certain behavior was punishable but also that it vould entail substantial sanctions rather than some token rebuke or deprivation. 
tions are attached to conduct he contemplates. ${ }^{28}$ Secondly, by specifying to enforcement officials exactly what the rule-maker intended to proscribe, precise rules lessen the freedom of those officials to make that determination for themselves. This diminishes the likelihood that enforcement officials will act arbitrarily or discriminatorily. ${ }^{20}$ Thirdly, the elimination of vagueness promotes the judicial function by informing courts of the rule-maker's perceived interest in governing conduct. Such insight into the purpose behind the rule enables a court to assess both the constitutionality of that rule and the fairness of its application to a given set of facts. ${ }^{30}$ Finally, when regulations identify with precision the conduct that is prohibited they reduce the "chilling effect"-the inhibition of freedom that emanates from uncertainty as to the scope of permissible conduct. ${ }^{31}$

28. The generally accepted formulation is contained in Connally v. General Constr. Co., 269 U.S. 385,391 (1926):

[A] statute which either forbids or requires the doing of an act in tcrms so vagute that men of common intelligence must necessarily guess at its meaning and differ as to its application violates the first essential of due process of law.

Elaboration of this rationale is found in Justice Frankfurter's dissenting opinion in Winters v. New York, 333 U.S. 507, 524 (1948). See also Giaccio v. Pennsylvania, 382 U.S. 399 (1966); United States v. Cardiff, 344 U.S. 174, 176-77 (1952); Winters v. New York, 333 U.S. 507 (1948); Lanzetta v. New Jersey, 306 U.S. 451, 453 (1939); Champlin Ref. Co. v. Corporation Comm. of Okla., 286 U.S. 210, 243 (1932); United States v. Cohen Grocery Co., 255 U.S. 81, 89 (1931); Collins v. Kentucky, 234 U.S. 634, 638 (1914); International Harvester Co. v. Kentucky, 234 U.S. 216, 221-23 (1914); Note, The Void-For-Vagueness Doctrine in the Stupromo Court, 109 U. PA. L. REv. 67, 68 (1960). In the university context, the fair notice rationale has been explicitly recognized in Soglin v. Kauffman, 295 F. Supp. 978, 984 (W.D. Wis. 1968), aff'd, 418 F.2d 163 (7th Cir. 1969).

29. See Buckley v. Meng, 35 Misc. 2d 467, 472, 230 N.Y.S.2d 924, 931 (Sup. Ct. 1962): The administrator, whether consciously or not, has substituted his own bias and predilection for the letter of the standard. And he has been able to do this bccausc the standard itself does not supply him with sufficient criteria for decision; the administrator has filled a decisional vacuum, so to speak.

See also Smith v. California, 361 U.S. 147 (1959); Watkins v. United States, 354 U.S. 178 (1957); Niemotko v. Maryland, 340 U.S. 268 (1951); Hague v. CIO, 307 U.S. 496 (1939); Connally v. General Constr. Co., 269 U.S. 385, 395 (1926); Note, Uncertainty in ColleGe Disciplinary Regulations, 29 OHo ST. L.J. 1023, 1028 (1968); Note, The Void-For-Vaguencss Doctrine in the Supreme Court, 109 U. PA. L. REv. 67, 80, 90 (1960).

30. See Cline v. Frink Dairy Co., 274 U.S. 445, 465 (1927); Gable v. Jenkins, 809 F. Supp. 998 (N.D. Ga. 1969), aff'd, 397 U.S. 592 (1970); People v. Scott, 26 N.Y.2d 286, 258 N.E.2d 206, 309 N.Y.S.2d 919 (1970); Note, The Void-For-Vagueness Doctrine in the Supreme Court, 109 U. PA. L. REv. 67, 80 (1960). The lawyer, an agent of the court, also finds precision helpful in preparing to represent his client. See United States v. McGlough, 263 A.2d 48 (D.C. Ct. App. 1970).

31. Keyishian v. Board of Regents, 385 U.S. 589 (1966); Elfbrandt v. Russcll, 381 U.S. Il (1966); Ashton v. Kentucky, 384 U.S. 195, 200 (1966); Dombrowski v. P'fister, 380 U.S. 479 (1965); Baggett v. Bullitt, 377 U.S. 360 (1964); NAACP v. Button, 371 U.S. 415 (1963); Cramp v. Board of Pub. Instruction, 368 U.S. 278 (1961); Smith v. California, 361 U.S. 147, I51 (1959); Thomas v. Collins, 323 U.S. 516, 530 (1945); Thornhill v. Alabama, 310 U.S. 88 (1940); Note, The Void-For-Vagueness Doctrine in the Supreme Court, 109 U. RA. L. REV. 67,75 (1960). 


\section{B. In Loco Parentis and Vague Rules}

The judicial failure to apply the vagueness doctrine to university rules was a natural corollary of the traditional legal view of the university suggested by the phrase in loco parentis. ${ }^{32}$ Under that view, it was assumed not only that universities possessed the inherent power to discipline but also that they would use that power benignly. At the same time, students were thought to regard university officials as friends, counselors or parents. According to this view, familial concern would fairly resolve conflicts within the community.

The argument that the university was entitled to act in loco parentis lent itself in several respects to a toleration of vague rules. Viewed as "children," students did not need precise rules because they could rely on "parents" to make their expectations reasonably understood, and, in any event, to temper discipline with understanding. ${ }^{33}$ Beyond this, the purpose of university education, like parental discipline, was

32. For a formulation of the in loco parentis doctrine, see John B. Stetson Univ: $v$ Hunt, 88 Fla. 510, 516, 102 So. 637, 640 (1924):

As to mental training, moral and physical discipline, and welfare of the pupils, college authorities stand in loco parentis and in their discretion may malse any regulation for their government which a parent could make for the same purpose ..... Classic cases applying the in loco parentis doctrine include Gott v. Berea College, $156 \mathrm{hy}$. 376, 161 S.W. 204 (1913); North v. Board of Trustees, 137 I11. 296, 27 N.E. 51 (1891); Clasen v. Pruhs, 69 Neb. 278, 95 N.W. 640 (1903); Anthony v. Syracuse Univ., 294 App. Div. 487. 231 N.Y.S. 435 (1928).

A rival "privilege" theory also led the older courts to give broad discretion to the rulemaking powers of universities. This doctrine was formulated in North v. Board of Trustecs, 137 III. 296, 306, 27 N.E. 54, 56 (1891):

The will of the student is necessarily subservient to that of those who are for the

time being his masters. By voluntarily entering the University or by being placed

there by those having the right to control him, he necessarily surrenders very many of his individual rights.

The notion that attendance at an institution of higher edueation constituted a privilege rather than a right was approved by the United States Supreme Court in Hamilton v. Regents of Unive of Cal., 93 U.S. 245 (1934). Iater Supreme Court cases, howerer, have explicitly rejected the view that the state can attach unconstitutional conditions to enjoyment of such governmental benefits. See, e.g., Keyishian v. Board of Regents, 385 U.S. 589 (1967). The Court has also repudiated the notion that attendance in a state univcrsity is a privilege and not a right. School Dist. of Abington Township y. Schompp, 374 US. 203, 251 (1963) (Brennan, J., concurring); Brown v. Board of Educ., 347 US. 483 , 493 (1954). Rccent cases in the lower federal courts have rejected the right-privilege distinction. Esteban v. Central Mo. State College, 415 F.2d 1077, 1089 (8th Cir. 1969), cert. denied, 398 U.S. 965 (1970); Pratz v. Louisiana Polytechnic Institute, 316 F. Supp. 872, 877 (W.D. La. 1970), appeal filed, 39 U.S.L.W. 3322 (U.S. Jan. 26, 1971) (No. 1252); Reichenberg v. Nelson, 310 F. Supp. 248, 252 (D. Neb. 1970). See generally Van Alstyne, The Demise of the RightPrivilege Distinction in Constitutional Law, 81 HARv. L. REv. 1439, 1442-49 (1908). Other university disciplinary cases flatly reject the idea that a university eduation, however it is labelled, is a luxury in modern society. Mfoore v. Student Affairs Comm. of Troy State Univ., 284 F. Supp. 725,731 (M.D. Ala. 1968); Knight v. State Bd. of Educ, 200 F. Supp. 174 (M.D. Tenn. 1961).

33. See Note, The Emerging Law of Students Rights, 23 ARk. L. REv. 619 (1970), More than a century ago, however, the court in Lander v. Seaver, 32 Vt. 114, 122-23 (1859), cautioned against overrating the "love and understanding" exhibited by cducators to their students. 
assumed to be character building rather than punishment. ${ }^{34}$ In ordering the relationship between student and administration precise rules seemed neither necessary nor appropriate. ${ }^{35}$

After dominating legal analysis in the area of student-university relations for many years, however, the in loco parentis doctrine has fallen into disuse. ${ }^{36}$ The changing realities of campus life have destroyed the assumptions upon which the doctrine was based. The small, closely-knit college has given way in great measure to relatively large and impersonal institutions. ${ }^{37}$ Not only has the mean age of college students risen dramatically, ${ }^{38}$ but also the responsibilities and privileges of citizenship have been extended to younger age groups. Undoubtedly in recognition of these and other changes, universities have abandoned conscious character-building as their primary educational mission. ${ }^{30}$ Suspension or expulsion of a student is more likely to be described today as punitive than remedial. ${ }^{40}$ In view of their rejection of the older

34. Pierce v. Society of Sisters, 268 U.S. 510 (1925); Kenney v. Gurley, 208 Ala. 628, 95 So. 34 (1923) (immorality); Douglass v. Campbell, 89 Ark. 254, 116 S.W. 211 (1909) (drinking); Tanton v. McKenney, 226 Mich. 245, 197 N.W. 510 (1924) (smoking); Statc ex rel. Dresser v. District Bd., 135 Wis. 619, 116 N.W. 232 (1908).

35. Carrington, Givilizing University Discipline, 69 Mrch. L. REv. 393, 400 (1971).

36. Moore v. Student Affairs Comm. of Troy State Univ., 284 F. Supp. 725, 729 (M.D. Ala. 1968); Zanders v. Louisiana State Bd. of Educ., 281 F. Supp. 747, 756 (W.D. La. 1968); Buttny v. Smiley, 281 F. Supp. 280, 286 (D. Colo. 1968); Goldberg v. Regents of Univ. of Cal., 248 Cal. App. 2d 867, 876-77, 57 Cal. Rptr. 468, 470 (1967); CorNeLl UNivexsitX, REPORT OF THE UNIVERSITY COMMISSION ON THE INTERDEPENDENCE OF UNIVERSITY RECULA TIONS AND Local, State and Federal Law (Sept. 27, 1967) (Prof. Allan P. Sindler, Chmn.); Beaney, Students, Higher Education, and the Law, 45 DENVER L.J. 511, 515 (1968); Van Alstyne, The Judicial Trend Toward Student Academic Freedom, 20 U. FLA, L. REV. 290, 292 (1968); Note, Developments-Academic Freedom, 81 HARv. L. REv. 1045 (1968).

No unified model has yet emerged to replace in loco parentis, but a "public service" model has been proposed on more than one occasion. See, e.g., Heyman, Some Thoughts on University Disciplinary Proceedings, 54 CALF. L. REv. 73, 74-75 (1966); Linde, Campus Law: Berkeley Viewed from Eugene, 54 GALIF. L. Rev. 40, 64.65 (1966). Morc recently, a civil-law model of student discipline, emphasizing restitution by wrongdoers to their victims, has been suggested. Carrington, Civilizing University Discipline, 69 Mrcrr. L. REv. 393, 409 (1971).

37. See Soglin v. Kauffman, 295 F. Supp. 978, 988 (W.D. Wis. 1968), aff'd, 418 F.2d 163 (7th Cir. 1969); Wright v. Texas S. Univ., 277 F. Supp. 110, 113 (S.D. Tex. 1967); Carrington, Civilizing University Discipline, 69 Mrcr. L. REv. 393 (1971); Van Alstync, The Student as University Resident, 45 DENVER L.J. 582, 591-92 (1968).

38. See Van Alstyne, The Student as University Resident, 45 DENVER L.T. 582,591 (1968), See also Soglin v. Kauffman, 295 F. Supp. 978, 988 (W.D. Wis. 1968), aff'd, 418 F.2d 163 (7th Cir. 1969); Note, Private Government on the Campus-Judicial Review of University Expulsions, 72 YALE L.J. 1362, 1380 (1963).

39. According to the Student Discipline Committce at the University of Oregon, " 'moral growth" or "character development" should not be included within the definition of the fundamental purposes of the University . . ." Linde, Camptus Law: Berkeley Viewed from Eugene, 54 CALIF. L. REv. 40, 43 n.5 (1966). See also Perkins, The University and Due Process, 62 AM. LiBraRY Ass's BuLL. 977, 980 (1968); Note, The Emerging Law of Students' Rights, 23 ARK. L. REv. 619, 626 (1970); Note, Private Government on the CampusJudicial Review of University Expulsions, 72 YALE L.J. 1362, 1380 (1963).

40. Commentators have recognized the punitive element in college discipline. "In the great majority of cases expulsion will constitute a penalty ... [S]chools would appcar unable to assert (as they might for lesser forms of discipline) that the purpose of their 
analogy to describe the student-university relationship, the courts might have been expected to recognize the possibility that vague rules would have a pernicious effect on campus. Thus, their continued reluctance to require precision in university rules is curious.11

\section{The Vagueness Doctrine and Its Application to University Rules}

According to the vagueness doctrine, ${ }^{, 2}$ whenever the (1) government seeks, through the (2) imposition of sanctions, to place (3) restraints on individual freedom it must avoid using language so (4) vague "that men of common intelligence must necessarily guess at its meaning and differ as to its application."43

Although some courts acknowledge that the elements of the vagueness doctrine are present in university disciplinary practices, they have at times raised a distinction between legislative and administrative bodies to justify less stringent application of the vagueness doctrine to campus regulations. ${ }^{44}$ The distinction assumes that courts as a general rule lack the expertise to make an independent judgment about the degree of precision attainable in areas, like student discipline, whose regulation has been delegated to administrative agencies. ${ }^{45}$ Whatever the validity of this assumption in the case of a particular administrative agency, the courts have evidently declined to adopt the legislative-administrative distinction as a reliable means of identifying those governmental restraints that they are capable of reviewing for vagueness. ${ }^{40}$ Rather, courts

action was not punishment." Note, Private Government on the Campus-Judicial Reviet of University Expulsions, 72 YALE L.J. 1362, 1392 (1963). Yet the courts have not almays acknowledged the punishment inherent in even the harshest sanction, expulsion. See General Order on Judicial Standards of Procedure and Substance in Review of Student Disci. pline in Tax Supported Institutions of Higher Education, 45 F.R.D. 133, 142 (W.D. MIo. 1968).

41. Carrington, Civilizing University Discipline, 69 MfraH. L. REv. 393, 400-01 (1971).

42. See note 25 supra, especially Note, The Void-for-Iagueness Doctrine in the Supreme Court, 109 U. PA. L. REV. 67, 94 (1960).

43. Connally v. General Constr. Co., 269 U.S. 385 (1926).

44. See Speake v. Grantham, 317 F. Supp. 1253, 1271-72 (S.D. Miss. 1970); Jones v. State Bd. of Educ, 279 F. Supp. 190, 202 (M.D. Tenn. 1968), affd, 407 F.2d 834 (6th Cir.), cert. granted, 396 U.S. 817 (1969), cert. dismissed, 397 U.S. 31 (1970); see also Collings, Unconstitutional Uncertainty-An Appraisal, 40 CoRNEL L.Q. 195, 233-37 (1955).

45. Esteban v. Central Mo. State College, 415 F.2d 1077, 1088 (8th Cir. 1969), affg 290 F. Supp. 622 (W.D. Mo. 1968), cert. denied, 398 U.S. 965 (1970); Speake v. Grantham, 317 F. Supp. 1253, 1272 (S.D. Miss. 1970).

46. The courts have frequently struck down administrative regulations for vauenes: M. Kraus \& Bros. v. United States, 327 U.S. 614 (1916) (Revised MFximum Price Regulation promulgated pursuant to the Emergency Price Control Act of 1912); Wilner v. Department of Health, 5 Misc. 2d 331, 159 N.Y.S.2d 601 (Sup. Ct. 1957) (regulation requiring that nursing homes employ certain types of personnel); State v. Aiartin, 7 N.C. App. 532,179 S.E.2d 47 (1970) (fishing regulation issued by the State Wildilife Resources Commission); Attic Club, Inc. v. Texas Liquor Control Bd., 450 S.TW.2d 149 (Tex. Civ. App. 1970) (regulh. tion governing operation of private clubs which hold liquor licenses); $c f$. United States $\mathrm{r}$. 
have chosen to confront the language of administrative regulations on the same footing as they have confronted statutory language--on a case by case basis to determine whether, in the context, greater precision could have been achieved.

Since application of the vagueness doctrine on campus should not turn on such a putative distinction, it is necessary to explore the dimensions of each element of the vagueness doctrine and to inquire whether these elements are, in general, present in campus disciplinary practices. Current "state action" doctrine under the Fourteenth Amendment suggests that not only "public," but also a good many "private" colleges and universities, reflect the first of these elements-the exercise of government power-when they prescribe campus rules. ${ }^{47}$

The second element of the doctrine, a restraint on personal freedom, is almost by definition present in every university regulation, for the very purpose of such regulations is to restrict the freedom of students to act as they please. In applying the doctrine in other contexts, courts have not been especially concerned with defining precisely the extent or type of the restraint on a particular freedom. Thus, in the area of assemblies, rules imposing an absolute ban on gatherings, rules requiring prior permission and rules merely limiting the time or place in which gatherings may occur have all been the subject of judicial scrutiny

Seaboard Airline R.R. Co., 225 F. Supp. 38 (E.D.N.C. 1964) (I.C.C. regulation pertaining to safe transportation of explosives). In Atwood's Transp. Lines, Inc. v. Unitcd States, 211 F.Supp. 168, 170 (D.C.C.), aff'd, 373 U.S. 377 (1962), it was said that "[r]ules and regula* tions promulgated by governmental establishments pursuant to statutory atuthority have the force and effect of law, and concededly are subject to the same tests as statutcs."

47. The conventional view continues to hold, however, that private universities are exempt from the strictures of due process. See, e.g., Dehaan v. Brandeis Univ , 150 F. Supp. 626 (D. Mass. 1957). In O'Leary v. Commonwealth, 441 S.W.2d 150, 156 (Ky,), cert. denicl, 396 U.S. 40 (1969), even the University of Kentucky was characterized as a "private place" and as "no different from private property." Recent claims that various levels and types of state support transform a nominally private into a public institution of higher learningt have been unsuccessful. Powe v. Miles, 294 F. Supp. 1269 (W.D.N.Y. 1968) (fact that oncfourth of total faculty and one-fifth of budget was allocated to ceramics college operated by Alfred University under contract with New York held insufficient to render the college an instrument of the state); Grossner v. Trustces of Columbia Univ., 287 F. Supp. 535 (S.D.N.X. 1968) (fact that private university performs public function in educating persons does not render its conduct state action so as to become subject to federal constitutional requirements, nor is receipt of money from the state, without more, enough to make the recipient an agency of government); Greene v. Howard Univ., 271 F. Supp. 609 (D.D.C. 1967) (large percentage of university expenses made by Congressional appropriations and power of Secretary of Health, Education and Welfare to control expenditures does not render university a governmental body).

For an expansive view of the "public function" idea, see Guillory v. Administrators of Tulane Univ., 203 F. Supp. 855 (E.D. La. 1962), vacated, 212 F. Supp. 674 (E.D. La. 1962); Note, Private Government on the Campus-Judicial Review of University Expulsions, 72 YALE L.J. 1362, 1381-83 (1963). On the applicability of the state action doctrine to private colleges and universities see O'Neil, Private Universities and Public Law, 19 BurFuto $L$. REv. 155 (1970); Note, Student Due Process in the Private University: the State Action Doctrine, 20 Syracuse L. Rev, 911 (1969); Note, 44 Tulane L. Rev. 184 (1969). 
for vagueness. Rather than focusing on the type or the restraining effect of the rule, courts tend to stress the importance of the freedom regulated. The freedom to assemble, for example, seems to be more precious to a community and thus more carefully guarded by the courts than the freedom to operate a motor vehicle. But though delineation of preferred freedoms may prompt special judicial scrutiny of rules, courts have not exempted other rules from scrutiny altogether.

The presence in university discipline of the third element-sanctions - has been the subject of greater controversy. Some courts have rejected the view that student discipline amounts to punishment at all, preferring to characterize it as an integral part of the educational process. ${ }^{48}$ Since most courts have taken the position, however, that whether university discipline is invoked for educational or punitive purposes, it inflicts harm upon a student, campus rules therefore meet the third element of the vagueness doctrine.

Although recognizing harm, the courts as a matter of practice have applied the vagueness doctrine with less rigor where that harm is not severe. ${ }^{49}$ Thus, a few courts have intimated that the standards of precision are lower when a civil sanction such as university dismissal is at stake, presumably because such a sanction is generally thought to be less severe than a criminal one. ${ }^{50}$ Admittedly, the majority of vagueness cases involve criminal enactments. 11 But as early as 1925 the

48. See, e.g., Speake v. Grantham, 317 F. Supp. 1253, 1272 (S.D. Mfiss. 1970); Estcban y. Central Mo. State College, 290 F. Supp. 622 (WD. Mo. 1968), af'd, 415 F2d 1077 (8th Cir. 1969), cert. denied, 398 U.S. 965 (1970).

49. Note, Due Process Requirements of Definiteness in Stalules, 62 Hasv. L. REv. 77, 85 (1948).

50. Winters v. New York, 333 U.S. 507, 515 (1948); Edgar A. Levy Leasing Co. v. Siegel, 258 U.S. 242, 250 (1922). Several opinions such as Esteban v. Central MIo. State College, 415 F.2d 1077, 1088 (8th Cir. 1969), aff'g 290 F. Supp. 622 (W.D. Mo. 1968), cert. denied, 398 U.S. 965 (1970), rely upon the civil-criminal distinction in upholding vague campus rules:

[T]t is not sound to draw an analogy between student discipline and criminal procedure. ... Certainly these regulations are not to be compared with the criminal statute. They are codes of general conduct which those qualificd and experienced in the field have characterized not as punishment but as part of the educational process itself and as preferably to be expressed in general rather than in specific terms.

See also Norton v. Discipline Comm. of E. Tenn. State Univ., 419 F2d 195, 200 (6th Cir. 1969), cert. denied, 399 U.S. 906 (1970); Speake v. Grantham, 317 F. Supp. 1253, I27I (S.D. Miss. 1970); Siegel v. Regents of Univ. of Cal., 308 F. Supp. 832, 836 (N.D. Calif. 1970). General Order on Judicial Standard of Procedure and Substance in Review of Student Discipline in Tax Supported Institutions of Higher Education, 45 F.R.D. 133, 142, 146 (W.D. Mo. 1968).

For an interesting discussion of the inadequacies of the analogy between criminal law and university discipline, see Carrington, Civilizing University Discipline, 69 Mfrcr. L. REv. 393 (1971).

51. Dickson v. Sitterson, 280 F. Supp. 486, 498 (Mr.D.N.C. 1968):

While the question of vagueness has most frequently arisen in criminal prosccutions, 
Supreme Court held that whether a penalty is criminal or civil is irrelevant to the need for precise rule-making. ${ }^{62}$ This seems sound, for, by itself, the fact that a penalty is denominated criminal or civil is not necessarily an accurate indication of its impact. Most courts have, in fact, disregarded the criminal-civil distinction in determining when circumstances warrant a meaningful vagueness inquiry. ${ }^{53}$

A more accurate measure of severity, and one to which the courts seem more responsive in other areas, is the degree to which a sanction disrupts an individual's life and forecloses him from future opportunities. ${ }^{54}$ For the student, suspension or expulsion from a university is obviously severe. 55 Besides constituting a social stigma, such sanctions

it has been applied in a variety of other situations where the obedience to a rule or standard has been exacted.

The following cases are leading examples of vagueness attacks on criminal enactments. United States v. Harriss, 347 U.S. 612 (1954) (fine and imprisonment); Boyce Motor Lines, Inc. v. United States, 342 U.S. 377 (1952) (fine and imprisonment); Winters v. New York, 333 U.S. 507 (1948) (misdemeanor); M. Kraus \& Bros. v. United States, 327 U.S. 614 (1946) (substantial criminal fines).

Interestingly, some universities incorporate the criminal law into their own misconduct codes. For example, one institution made punishable "[a]ny act in violation of city, county, state or federal law." Jones v. State Bd. of Educ., 279 F. Supp. 190, 201 (M.D. Tenn. 1968), aff'd, 407 F.2d 834 (6th Cir.), cert. granted, 396 U.S. 817 (1969), cert. clismissed, 397 U.S. 31 (1970). Thus identical language may be valid or invalid under the vagueness doctrine depending on whether it is used as a standard of behavior on campus or off.

52. A. B. Small Co. v. American Sugar Ref. Co., 267 U.S. 233, 239 (1925):

The ground or principle of the [Cohen and Weed] decisions was not such as to be applicable only to criminal prosecutions. It was not the criminal penalty that was held invalid, but the exaction of obedience to a rule or standard which was so vague and indefinite as really to be no rule or standard at all.

According to one commentator:

No logical basis can be found for such a [civil-criminal] distinction, since notice to the persons affected may be equally as important in one case as in the other. It might even be argued that it is more important in the case of civil statutes, since such statutes are more often looked to for guidance before the act than are criminal statutes.

Comment, Legislation-Requirement of Definiteness in Statutory Standards, 53 Micit. I. REV. 264, 273 (1954).

53. Government enactments whose violation led to civil sanctions have been struck down for vagueness in the following cases: Feinglass v. Reinecke, 48 F. Supp. 438 (N.D. Ill. 1942) (loss of right to appear on election ballot); Hewitt v. State Bd. of Medical Ex. aminers, 148 Cal. 590, 84 P. 39 (1906) (revocation of certificate to practice medicinc); parks v. Libbey-Owens-Ford Glass Co., 360 Ill. 130, 195 N.E. 616 (1985) (liability for civil damages); Chicone v. Liquor Control Comm'n, 20 Ohio App. 2d 43, 251 N.E.2d 864 (1969) (suspension of liquor license); Booth v. Commonwealth, 197 Va. 177, 88 S.E.2d 916 (1955) (loss of right to purchase or possess alcoholic beverages); $c f$. Pike v. CAB, 303 F.2d 358 (8th Cir. 1962) (loss of fiying license).

As recently as 1967, the Supreme Court reiterated in dicta that "the 'void for vagueness' doctine [is] applicable to civil as well as criminal actions." Boutillier v. Immigration and Naturalization Serv., 387 U.S. 118, 123 (1967).

54. See note 53 supra, especially Pike v. CAB, 303 F.2d 353, 357 (8th Cir. 1962).

55. The district court opinion in Soglin v. Kaufman, 295 F. Supp. 978, 988 (W.D. Wis. 1968), aff'd, $418 \mathrm{~F} .2 \mathrm{~d} 163$ (7th Cir. 1969), took judicial notice that:

[T] $n$ the present day, expulsion from an institution of higher learning, or suspension for a period of time substantial enough to prevent one from obtaining academic credit for a particular term, may well be, and often is in fact, a more severe sanction 
interrupt or terminate a student's academic training and may ruin the college record on which his career depends. Thus the highest standards of precision would seem warranted for rules that impose these sanctions. At the other extreme will normally lie such inconsequential penalties as a small monetary fine, an official reprimand, or a brief loss of social privileges, all of which would justify less rigorous application of the doctrine. Between these extremes falls a wide variety of sanctions. The exact location of a particular penalty on the spectrum of severity will depend upon the court's weighing of relevant factors. ${ }^{50}$ Thus, for example, if called upon to evaluate the severity of a student's disqualification by school administrators from membership in a legal honor society, a court might inquire whether the complainant could still practice law, choose his field of specialization, attract clients and earn as high an income as society members. ${ }^{57}$

The mere fact that sanctions in a given case are not especially severe does not, of course, foreclose a rigorous application of the vagueness doctrine. As noted, when constitutionally preferred freedoms are involved, rules imposing penalties substantially less severe than suspension or expulsion have been subjected to the highest standards of precision. ${ }^{58}$

Vagueness itself, the fourth element of the doctrine, has been extremely difficult for courts to identify in practice. ${ }^{59}$ The doctrine seeks above all to assure that a government enactment is sufficiently clear to all those who must look to it for guidance-the individual in planning

than a monetary fine or a relatively brief confinement imposed by a court in a criminal proceeding.

The court did not decide whether the vagueness doctrine is applicable to disciplinary regulations whose potential sanctions are mild, such as a denial of social privileges or a minor loss of academic credit. Id. at 991 . The severity of university dismissils, hovicier, is almost universally recognized today. See, e.g., Dixon v. Alabama State Bd. of Educ, 291 F.2d 150, 157 (5th Cir.), cert. denied, 368 U.S. 930 (1961); Note, Privale Government on the Campus-Judicial Review of University Expulsions, 72 YALE L.J. 1362, 1363-65, 1592 (1963). 56. The mere notation of disciplinary action of any seriousness on a student's record may jeopardize his future. If a court is sympathetic to this and accords it great weight, penalties milder than suspension or expulsion will presumably meet the test of substantial harm.

57. While vagueness was not an issue in Blatt v. University of S. Cal, 5 Cal. App. 3d 935, 942, 85 Cal. Rptr. 601, 606 (1970), the court consulted such factors in evaluating the severity of non-election.

58. See notes 21-24 supra.

59. Justice Frankfurter's dissent in Winters v. New York, 393 U.S. 507, 524 (1948) is the classic exposition of the difficulties of identifying vagueness and achieving precision: But "indefiniteness" is not a quantitative concept. It is not even a technical concept of definite components. It is itself an indefinite concept. There is not such a thing as "indefiniteness" in the abstract, by which the sufficiency of the requirement expressed by the term may be ascertained. . . That which may appear to be too vague and even meaningless as to one subject matter may be as definite as another subject matter of legislation permits. ... 
his future conduct according to it, the government official in enforcing it, and the courts in reviewing its constitutionality and overseeing its application. In measuring its effectiveness in supplying this guidance, courts have examined statutory language in the light of a number of relevant factors: common understanding and usage of the words employed, background and knowledge of the individuals affected, prior judicial and administrative interpretations and the possibility of greater precision. Obviously, deciding whether a regulation is sufficiently definite to satisfy due process is a delicate and complex task. Moreover, since vagueness is fundamentally a matter of degree, courts are likely to disagree over what regulations are unconstitutionally vague. ${ }^{\text {(0) }}$ Should a regulation be found void for vagueness, courts may also disagree on its cure. Thus one court may be satisfied by the substitution of the word "disorderly" for "ungentlemanly" in a given rule while another might find those words equally unacceptable.

The doctrine would probably prove no less elusive on campus than off. University rules, like rules elsewhere, differ in the degree to which their language provides the guidance required by due process. But those regulations that lie at the extreme of indefiniteness, the catchall rules described earlier, ${ }^{61}$ should surely fall under any application of the doctrine.

\section{The Special Nature of the University Setting}

Like the multitude of government enactments subjected to the constitutional requirement of precision, many university disciplinary regulations satisfy the prerequisites of the vagueness doctrine. But more than a lawyer's impulse to extend a doctrine to new areas underlies the logic of this Note. In the special context of the academic community, the evils which the requirement of precision was designed to prevent $t^{02}$ assume unusual proportions and give to the vagueness doctrine itself particular urgency.

Initially the evil of inadequate warning that inheres in vague rules would not seem any more grave on campus than off. It is true that students should find it no harder to derive adequate warning from the

60. See generally Frankfurter, Some Reflections on the Reading of Statutes, 47 ColuM. L. REv. 527, 528 (1947); Freund, The Use of Indefinite Terms in Statutes, 30 Yale L.J. 497 (1921).

61. See p. 1262 supra. This seems especially likely since some courts, in refusing to apply the vagueness doctrine on campus, have nonetheless acknowledged the vagucness of many of the rules currently in use. Buttny v. Smiley, 281 F. Supp. 280, 283 (D. Colo. 1968).

62. See p. 1266 supra. 
actual words of a university rule than from any other government enactment. But courts hold that a standard of conduct whose actual words are vague may still provide sufficient notice if a precise meaning can be imputed to it from community norms. ${ }^{03}$ Such "constructive notice," however, should not be easily inferred on campus, ${ }^{\text {of }}$ for it requires that there be informal agreement on behavioral standards. Such consensus probably characterized some closely-knit college communities in the past. But the changing realities alluded to earlier ${ }^{60}$ cast increasing doubt on the assumption that such a consensus exists on most campuses today. Through their admissions policies, universities temporarily bring together a culturally diverse cross-section of students. ${ }^{60}$ Through the education they offer, they foster independence, creativity-and often therefore nonconformity. These developments have occurred on campuses where, as part of society's growing cultural and political cleavages, students more frequently disagree not only among themselves but also

63. FTC v. R.R. Keppell \& Bros., Inc., 291 U.S. 304, 312-13 (1934); Fox v. Washington, 236 U.S. 273, 277 (1915); Nash v. United States, 229 U.S. 373 (1913); Smiley v. Kansas, 196 U.S. 447 (1905). In Carr v. St. John's Univ., 17 App. Div. 2d 632, 231 N.Y.S.2d 410, rev'g 34 Misc. 2d 319, 231 N.Y.S.2d 403 (Sup. Ct.), aff'd mem., 12 N.Y.2d 802, 187 N.E.2d 18, 235 N.Y.S.2d 834 (1962), the New York Appellate Division reversed a lower court's reinstatement of students who had been dismissed for taking part in a civil marriage ceremony. To do so, it assumed that to Catholic students and authorities at a Catholic university, the standard of behavior requiring students to act "[i]n conformity with the ideals of Christian education and conduct" would be understood to mean "Catholic" ideals, under which participation in such a ceremony would be disapproved. Sec also the references to community norms in Buttny v. Smiley, 281 F. Supp. 280,285 (D. Colo. 1968) and in Goldberg v. Regents of Univ. of Cal., 248 Cal. App. 2d 867, 850, 57 Cal. Rptr. 463, 472 (1967).

64. The existence of several groups on campus whose norms may be radically different is one reason that constructive notice should not readily be inferred. As one commentator put it, "Is it the conduct of the community, the administration, the faculty, or onc's fellow students one must use as a standard of acceptability" Note, Uncertainty in College Disciplinary Regulations, 29 Omo ST. I.J. 1023, 1030 (1968).

65. See p. 1268 supra.

66. The lower court in Carr v. St. John's Univ., 34 Misc. 2d 319, 324, 231 N.Y.S.2d 403, 410 (Sup. Ct), rev'd, 17 App. Div. 2d 632, 231 N.Y.S.2d 410, affd mem., 12 N.Y.2d 802, 187 N.E.2d 18, 235 N.Y.S.2d 834 (1962), took notice of the heterogeneity of college students, even of those attending a Catholic university, by observing that the standard in question was susceptible to "a variety of meanings, each subject to different interpretation by students of different backgrounds." Commentators have more frequently called attention to the growing diversity within the university population. According to Wilson, Campus Freedom and Order, 45 DENVER L.J. 502, 506 (1968):

Confronting the realities involves taking into account the fact that many institutions today are large and heterogeneous aggregations of human beings with competing and sometimes conflicting purposes. - . Their size and heterogeneity, their increased outside involvements, their enhanced importance, their enmeshment in processes of rapid social change-these, and other circumstances, give new and enlarged dimensions to the problems of campus freedom and order.

See also Van Alsyne, Student as University Resident, 45 Denrer L.J. 582, 591-92 (1968). The fact that the student population changes every four years has also been cited as evidence for the need to give clear guidance to students in determining their bchavior. Note, Private Govemment on the Campus-Judicial Review of University Expulsions, 72 Yars: L.J. 1362, 1403-04 (1963). 
with those who make and enforce the rules that govern them. A consensus on behavioral norms is unlikely in a community of this description and cannot be relied upon to provide the adequate warning absent in vague rules.

Furthermore, the second vice of vagueness-the potential for vague rules to be applied arbitrarily and discriminatorily-is often heightened on campus. ${ }^{67}$ In expressing political dissent or experimenting with novel life-styles, students are challenging not only distant political figures and abstract social norms but also the administrator or faculty member who directly governs their college life. They represent a threat both to his authority and position on campus and to the personal values-cultural, social, and political-that he may hold. Since the administrator or faculty member may come into daily contact with students who offend him, this threat to his position and values may seem to him all the more im. mediate and pervasive and furnish him with special incentive to make use of the arbitrary and discriminatory potential of vague rules. ${ }^{08}$ So motivated, he may call upon any of his strategically placed colleaguesadministrators, faculty, and enforcement officials with whom he works so closely in the academic community-to initiate disciplinary proceedings. There is a greater immediacy between the individual and the policing mechanism on campus than there is elsewhere in society. At the same time, persons outside the academic community may also exert the usual pressures upon enforcement officials to discipline in an arbitrary or discriminatory fashion. ${ }^{69}$

Undoubtedly many students are aware of their vulnerability to reprisals from campus figures whose authority and values they challenge. This fear of the opportunity given university administrators to act arbitrarily and discriminatorily makes students reluctant to take a full part in campus activities. ${ }^{70}$ Even apart from this fear, vague rules necessarily generate a clouded and uncertain environment. Students cannot

67. Perkins, The University and Due Process, 62 As. LinRsRy Ass'N BuLs, 977, 980 (1968):

... [A]rbitrariness is not unknown in the most elite intellectual circles. Administrators are not uniformly capable of distinguishing between what they consider desirable and what is acceptable to a consensus of the community. Operating under pressure, as administrators do much of the time, they can be insensitive to the most rudimentary forms of justice and fair play.

See also Wright, The Constitution on the Campus, 22 VAND. L. Rev. 1027, 1086 (1969). 68. See Note, Uncertainty in College Disciplinary Regulations, 29 OHo ST. L.J. 1023, 1031, 1035-36 (1968).

69. Id. at 1034; see, Wright, The Constitution on Campus, 22 VAND. L. Rxv. 1027, 1081 (1969).

70. Note, Uncertainty in College Disciplinary Regulations, 29 Owo Sr. L.J. 1028, 1085 (1968). 
feel at liberty to exercise the freedom they possess if they are unsure of its borders. Such inhibition is one of the evils, the "chilling effect," that the vagueness doctrine seeks to eliminate. ${ }^{71}$ Since a university community depends heavily on the vigorous exercise by its members of their freedoms, ${ }^{72}$ in particular their First Amendment rights to speak and to write as well as to utilize less conventional means of expression, the indirect chilling of those freedoms is especially pernicious on campus. If one of its purposes is to encourage individual free inquiry, the academic community, more than any other, will suffer from governance by vague standards. ${ }^{73}$

\section{The Gase against Precise Rules}

\section{A. University Autonomy}

The most common explanation offered by the courts for their decision to keep the vagueness doctrine off campus is that judicial intervention to require regulatory precision would unduly interfere with the functioning of the university. ${ }^{74}$ It is difficult to understand what is meant when the courts, as they so often do, describe student discipline as "a proper exercise of [the university's] inherent general powers to maintain order on the campus,"75 or premise it upon "the wide discretion traditionally given school officials in administration of their affairs."76 Such characterizations conceal why the university's rules are

71. See TAN p. 1266 supra.

72. In Sweezey จ. New Hampshire, 354 U.S. 234, 250-51 (1957), Chicf Justice Warren explained the importance of the First Amendment to the university:

The essentiality of freedom in the community of American universitics is almost selfevident. No one should underestimate the vital role in a democracy that is played by those who guide and train our youth. To impose any strait jacket upon the intellectual leaders in our colleges and universities would imperil the future of our Nation. . . .

Teachers and students must always remsin free to inquire, to study and to evaluate, to gain new maturity and understanding; otherwise our civilization will stagnate and die.

Similar statements have been made more recently in Tinker v. Des Mroines Independent Community School Dist., 393 U.S. 503, 511 (1969) and Epperson v. Arkansas, 393 U.S. 97. 104 (1968).

73. Vague university rules may impair judicial review no more than do vague rules elsewhere. But the campus, as shown above, remains unusually vulnerable to the other evils of vagueness.

74, See, e.g., Speake v. Grantham, 317 F. Supp. 1253, 1272 (S.D. Miss. 1970); Zanders v. Louisiana State Bd. of Educ., 281 F. Supp. 747, 757-58 (WD. La. 1968); Buttny v. Smiley, 281 F. Supp. 280, 285-86 (D. Colo. 1968); Regents of Univ. of Cal., 248 Cal. App. 2d 867, 57 Cal. Rptr. 463 (1967). Schuyler v. State Univ., 31 App. Div. 2d 273, 297 N.Y.S.2d 363 (1969); Goldstein v. New York Univ., 76 App. Div. 80, 78 N.Y.S. 7 S9 (1902); State ex rel. Sherman v. Hyman, 180 Tenn. 99, 171 S.W.2d 822 (1942); cert. denied, 319 U.S. 748 (1943).

75. Goldberg v. Regents of Univ. of Cal., 248 Cal. App. 2d 867, 881, 57 Cal. Rptr. 463, 473 (1967).

76. Zanders v. Louisiana State Bd. of Educ, 281 F. Supp. 747, 767 (W.D. Ia. 1968). 
immune to judicial review for vagueness. ${ }^{77}$ However, inferences from the cases suggest that two related but distinguishable concerns underlie the courts' reluctance to impose upon the draftsmen of university regulations a requirement of precision. First, judicial intrusion onto the campus might substitute the courts' own inexpert views for those of university officials. ${ }^{78}$ Secondly, whether or not judicially mandated, precise rules might deprive administrators of the flexibility they need to deal with the diverse problems that arise in their community. ${ }^{79}$ Analysis of both concerns suggests that neither warrants judicial acquiescence in vague university rules.

\section{The Impact of Judicial Intrusion: Inexpertise}

The vagueness doctrine does not call upon judges to second-guess the university on the substance of its disciplinary policy. In striking down a vague university rule, courts would not substitute their own views on what student conduct to punish. Instead they would encourage the university to reformulate its own interests, subject, of course, to substantive constitutional limitations. By definition, the vagueness doctrine only requires that the university define prohibited conduct with precision and clarity. The doctrine is a familiar judicial tool and, like the due process hearing for university discipline required by Dixon $v$. Alabama State Board of Education, ${ }^{80}$ is predicated on the competence of courts to assess the fairness of form.

77. The use by courts of such conclusory arguments has concealed the precise interests at stake. As one commentator stated: "[O]ne of the problems with student cascs all along was that the school's discretion was assumed rather than analyzed." Note, The Emerging Law of Students' Rights, 23 ARK. L. REv. 619, 623 (1970). Cf. Perkins, The University and Due Process, 62 AM. LIBrary Ass'N Bulr. 977, 981 (1968). See also Note, Private Government on the Campus-Judicial Review of University Expulsions, 72 YALE L.J. 1362, 1366 (1963).

78. According to the court in Healy v. James, $311 \mathrm{~F}$. Supp. 1275, 1282 (D. Conn. 1970):

No court should interfere in reviewing the wisdom of any [university] policy adopted,

provided there is no invasion of constitutional due process of law, substantively or procedurally. It is not the business of the court nor is it within its prerogative to interfere with or attempt to administer college rules and regulations.

See also Speake v. Grantham, 317 F. Supp. 1253, 1272 (S.D. Miss. 1970). The notion that courts ought not to interfere with so-called "academic judgments" has prevailed since the earliest cases. North v. Board of Trustees, 137 Ill. 296, 27 N.E. 54 (1891); Pcople ex rel Pratt v. Wheaton College, 40 Ill. 186 (1866). Woods v. Simpson, 146 Md. 547, 126 A. 882 (1924); People ex rel. Goldenkoff v. Albany Law School, 198 App. Div. 460, 191 N.X.S. 349 (1921); Koblitz v. Western Reserve Univ., 11 Ohio Cir. Dec. 515, 525, 21 Ohio Cir. Ct. R. 144 (1901). At least one university president has expressed concern that courts may soon be substituting their judgment for that of university administrators, Perkins, The Universily and Due Process, 62 AM. LlBrary Ass'N Bull. 977, 978, 980.81 (1968).

79. See Esteban v. Central Mo. State College, 290 F. Supp. 622, 629 (W.D. Mo. 1968), aff'd, 415 F.2d 1077 (8th Gir, 1969), cert. denied, 398 U.S. 965 (1970); Due v. Florida A \& M Univ., 233 F. Supp. 396, 403 (N.D. Fla. 1963). See also General Order on Judicial Standards of Procedure and Substance in Review of Student Discipline in Tax Supported Institutions of Higher Education, 45 F.R.D. 133 (W.D. Mo. 1968); Note, 48 N.C.L. REV, 943, 947 (1970).

80. 294 F.2d 150 (5th Cir. 1961), rev'g 186 F. Supp. 945 (M.D. Ala. 1960), cert. denied, 
However limited the intrusive effect of the vagueness doctrine, there is a class of standards, commonly called "academic," to which the doctrine should probably not apply. Within this class clearly fall standards established by the university to evaluate student scholastic performance on examinations and papers and to determine the overall level of achievement required for a degree and for academic honors. Because these standards and their application in a given case reflect the judgment of persons familiar with the educational process, the courts, as a prudential matter, have exercised restraint in reviewing their reasonableness and their particular applications. ${ }^{81}$ Perhaps the same considerations should make courts wary of evaluating even the precision of those standards.

However, as we move away from these purely "academic" judgments toward other spheres of student life such as extracurricular activities, off-campus conduct and modes of dress, the courts have shown considerably greater willingness to review substantively both the reason-

368 U.S. 930 (1961). Dixon held that before a student attending a tax-supported institution of higher learning may be expelled for misconduct he is entitled to notice, a statement of the charges against him, the names of witnesses and the nature of their proposed testimony. and, most importantly, the opportunity to present his defense before a disciplinary body whose report is to be made available for his inspection. For application and claboration of the Dixon requirements, see, e.g., Wright v. Texas S. Univ., 392 F.2d 728 (5th Cir. 1968), aff' 277 F. Supp. 110 (S.D. Tex. 1967); Scoggin v. Lincoln Univ., 291 F. Supp. 161 (WD. Mo. 1968); Esteban v. Central Mo. State College, 277 F. Supp. 619 (W.D. Mich. 1967); Due v. Florida A. \& M. Univ., 233 F. Supp. 390 (N.D. Fla. 1963); Knight v. State Bd. of Educ, 200 F. Supp. 174 (M.D. Tenn. 1961); Woody v. Burns, 183 So. 2 d 56 (Fla. Dist. Ct. App. 1966). For an earlier case foreshadoving Dixon, see State ex rel. Sherman v. Hyman, 180 Tenn. 99, 177 S.W.2d 822, cert. denied, 319 U.S. 748 (1912).

Courts have disagreed over whether the right to counsel is included within the right of state university students to procedural due process. In Madera v. Board of Educ of City' of New York, 386 F.2d 778 (2d Cir.), rev'g 267 F. Supp. 356 (S.D.N.Y. 1967), cert. denied, 390 U.S. 1028 (1968); Wasson v. Trowbridge, 382 F.2d 807 (2d Cir.), rev'g 269 F. Supp. 900 (E.D.N.Y. 1967); and Barker v. Hardway, 283 F. Supp. 228 (S.D. W. Va.), aff'd, 399 F. Id 638 (4th Cir. 1968), cert. denied, 394 U.S. 905 (1969), courts refused to impose the requirement. But the opposite result was reached in French v. Bashful, 303 F. Supp. 1333, 1338 F.D. L.s. 1969), Zanders v. Louisiana State Bd. of Educ., 281 F. Supp. 747, 752 (E.D. La. 1968), and Esteban v. Central Mo. State College, 277 F. Supp. 649, 651 (V.D. MTo. 1968).

When the student faces only minor sanctions, courts have dispensed with the Dixon requirements. E.g., Perlman v. Shasta Joint Junior College Dist. Bd. of Trustees, 9 Cal. App. 3d 873, $88 \mathrm{Cal}$. Rptr. 563 (1970). But see Stricklin v. Regents of Univ. of WVis., 297 F. Supp. 416 (W.D. Wis. 1969).

81. The courts uniformly eschew reviewing grades or other indicia of scholastic performance. Wright v. Texas S. Univ., 277 F. Supp. 110, 111-12 (S.D. Tex. 1967), affd, 392 F.2d 728 (5th Cir. 1968); Dehaan v. Brandeis Univ., 150 F. Supp. 626 (D. Mass. 1957); Mustell v. Rose, 282 Ala. 358, 211 So. 2d 489, cert. denied, 393 U.S. 936 (1968); West v. Board of Trustees of Miami Univ., 41 Ohio App. 367, 181 N.E. 144 (1931). Perhaps the most frequently cited case for this refusal is Connelly v. University of Vt., 244 F. Supp. 156, 160 (D. Vt. 1965):

The reason for this rule is that in matters of scholarship, the school authorities are uniquely qualified by training and experience to judge the qualifientions of a student, and efficiency of instruction depends in no small degree upon the school finculty's freedom from interference from other noneducational tribumals.

See generally Beaney, Students, Higher Education and the Law. 45 Dewves I.J. 511, 519.20

(1968); Wright, The Constitution on the Campus, 22 VAND. L .REv. 1027, 1069-70 (1969). 
ableness and application of university rules, presumably because they feel more qualified to deal with such subject matter. ${ }^{82}$ If these spheres of student life are appropriate subjects of substantive judicial review, it seems odd that they should still lie beyond reach of the vagueness doctrine.

\section{The Impact of Precise Rules: Loss of Flexibility}

A second objection to applying the vagueness doctrine to university disciplinary rules is that precision, whether or not judicially mandated, deprives university administrators of the flexibility they need to denl with the diverse problems that may arise on a university campus. ${ }^{83}$ Courts have frequently endorsed this view but have offered little explanation and no proof of how precise rules would interfere with the capacity of the college administration to govern. One can, however, imagine several ways in which precise rules might reduce the flexibility needed by those who must govern the university.

One argument is that the formulation of a precise code would divert the attention of members of the university community from more conventional academic pursuits. ${ }^{84}$ Obviously, someone will have to devote

82. See, e.g., Pratz v. Louisiana Polytechnic Institute, 316 F. Supp. 872 (W.D. La. 1970), appeal filed, 39 U.S.L.W. 3322 (U.S. Jan. 26, 1971) (No. 1252) (requirement that students live and eat meals in university facilities upheld as reasonable); Reichenberg v. Nelson, 810 F. Supp. 248 (D. Neb. 1970) (college rule banning long hair held unreasonable in absence of showing that such hair in fact disrupts educational process); Mollere v. Southeastern La. College, 304 F. Supp. 826 (E.D. La. 1969) (college rule requiring minor female students to live on campus, while allowing others to live off campus, where only reason offered was need to fill dormitory vacancies, held unreasonable); Calbillo v. San Jacinto Junior Collegc, 305 F. Supp. 857 (S.D. Texas 1968) (prohibition against beards on campus held invalid in absence of rational relationship to health, welfare, morals or discipline of students); Moore v, Student Affairs Comm. of Troy State Univ., 284 F. Supp. 725 (M.D. Ala. 1968) (state university rule reserving the right of officials to enter and inspect dormitory rooms held reasonable as necessary to institution's operation); Zachry v. Brown, 299 F. Supp. 1860 (N.D. Ala. 1967) (university classification of male students by their hair style, based on personal dislike of long hair, held unreasonable and a violation of equal protection); Sigma Chi Fraternity v. Regents of Univ, of Colo,, 258 F. Supp. 515 (D. Colo. 1966) (campus ban on racially restricted fraternities upheld as reasonably required to preserve an atmosphere conducive to study).

83. See note 79 supra.

84. Commentators disagree on the extent to which a requircment of precision would divert resources from other pursuits. A pessimistic note was sounded in Note, 5 HovstoN L. REv, 541, 547 (1968):

The courts have never stated that a university must provide a specific regulation for

every type of forbidden conduct. Such a prescription would force university officials

to spend unknown time drafting regulations rather than carrying out more pressing administrative duties.

In direct response to this assertion, however, Professor Charles Wright, who participatcd in the drafting of a precise code at the University of Texas, asked "WWhat more pressing duty is there for any of us involved in the life of a university than to put our jnternal affairs into a condition that will narrow 'the gap of mistrust and, hopefully, spare our campus the anguish of Berkeley and Columbia." Wright, The Constitution on the Campus, 
the extra measure of time and energy that the drafting of precise rules requires. But this expenditure of resources would not be as great in the long run as it might at first seem. The drafting of a precise code would entail an initial investment of time and energy, but once drawn it need only be periodically updated as experience under the code and changing circumstances recommend. Further, the development of model codes by a few universities will lessen the rule-making burden on others. ${ }^{85}$ Once formulated, such codes can be adapted to the special needs and features of these other universities with minimal investment of administrative talent. ${ }^{86}$

Of course, to the extent that members of the university community are engaged in this endeavor, they will be diverted from the more conventional duties of studying, teaching and research. But, a high level of attention to the drafting of student disciplinary rules should not be regarded as a waste or misallocation of resources, not only because these rules have generated controversy on campus, ${ }^{67}$ but because a good many educational opportunities may inhere in hammering them out. Among these might be numbered the formulation and defense of one's personal and social values and articulation of them in concrete language. ${ }^{88}$ For example, a code provision which regulates political demonstrations requires a thoughtful balance between the interests of the university community in preventing disruption of its operations, on the one hand, and in promoting expression of beliefs, on the other. Viewed in light of this educational potential, the attention of students, faculty and administrators to the problems of precise rulemaking seems more an integral part of academic life than a diversion from it. ${ }^{89}$

22 VAND. L. REv. 1027, $1069-64$ (1969). See also Carrington, Civilizing University Discipline, 69 MICH. L. REv. 393, 405 (1971).

85. See, e.g., The University of Oregon Student Conduct Program, reprinted and discussed in Linde, Campus Law: Berkeley Viewed from Eugene, 54 CuLAF. I. REv. 10, 47, 67 (1966); $A B A$ Section on Individual Rights and Responsibilities, $A$ Statement of the Rights and Responsibilities of University Students (Nov. 1, $1969 \mathrm{draft}$ ).

86. Precise rules will also save the disciplinary panel the effort that would otherwise be required to decide the meaning of the university's general misconduct rules before applying them to a given case.

87. Wright, The Constitution on the Campus, 22 VAND. L. REv, 1027, 1064 (1969).

88. Clinical programs to develop forensic and legislative skilis have already become standard features of law schools where their academic relevance is apparent.

89. Several other advantages of precise rules are closely related. Participation by the entire community in the rule-making process will provide the additional culuational op. portunity for practical experience in self-government. Aforeover, if it is true that a community best obeys laws that are enacted with its participation and consent, such a code will be more effective. See Joint Statement on Student Rights and Freedom of Students, art. IV(c), 43 AMr. Ass'N. U. Prof. BULr. 365 (1967); Carrington, Civilizing Universily Discipline, 69 MIrce. I. REv. 393, 399-100 (1971). 
Difficulties not only in the formulation of precise rules but in their implementation as well may account for the courts' fear that a loss of administrative flexibility will result from application of the vagueness doctrine on campus. Specifically, student codes that forbid misbehavior in precise terms and provide for its punishment would arguably limit administrative options in two respects. Officials might find themselves compelled to punish the proscribed conduct whenever it occurred, and they might be prevented from punishing behavior unmentioned in the code. In assessing the magnitude of these constraints, it may be helpful to identify types of situations whose special characteristics demand a flexible response.

One such situation requiring flexibility is disciplinary action against a student offender who mistakenly violated a rule, appears genuinely repentant, or for any other reason would benefit from a relaxation of discipline. Precise rules would seem to preclude leniency toward him, since there inheres in their plain meaning a pressure, absent in vague rules, toward literal, and often harsh, application. Precision thus curtails prosecutorial discretion-the decision whether or not to bring charges.

But the discretion afforded enforcement officials by vagueness in the definition of substantive offenses is not the university's sole source of flexibility. The disciplinary panel itself will have ample occasion to be lenient since it retains the opportunity to interpret the university's regulations before applying them and to allow a student a range of defenses. ${ }^{30}$ Even if the panel finds him guilty it will ordinarly have latitude in fixing a penalty. ${ }^{91}$ In so doing, it may consider the circumstances of the violator and the violation, including all extenuating factors, in mitigating or otherwise tailoring the punishment to suit the individual case.

A second type of situation in which precise rules might prevent a flexible response is the case of a student whom administrators regard as generally unsuited to the institution but who, having violated no specific regulation, cannot be punished. ${ }^{92}$ This student may be socially or emotionally disturbed, lacking in motivation, simply immature or otherwise unready for college. He would arguably benefit from a tem-

90. The opinion in Speake v. Grantham, 317 F. Supp. 1253, 1284 (S.D. Miss, 1970), cxplicitly recognized the latitude enjoyed by a disciplinary panel in the fact-finding process.

91. For an example of the typical misconduct regulation which specifically delegates un. fettered discretion to university officials to determine penalties, see note 9 supra.

92. For a description of the generally-unsuited student, see Note, Private Government on the Campus-Judicial Review of University Expulsions, 62 YALE L.J. 1362, 1992 (1963). 
porary or even permanent severance from the university. Undoubtedly there are those students who would reject an informal recommendation by the university that they voluntarily withdraw from college. But, taken together, a number of the university's well-established prerogatives seem to render vague rules unnecessary in meeting this situation. The university's control over its admissions standards and procedures enables it at an early stage to reject the applicant who for any reason appears "generally unsuited." 93 Although a student's unreadiness for college may not be detected at this early stage, his maladjustment so frequently entails substandard scholastic performance that the university's unquestioned authority over academic affairs will often permit it to handle his case. Indeed, the university has the virtually unqualified privilege not only to establish its own academic standards but also to apply those standards to an individual's performance. ${ }^{81}$ In any event, this student may be more appropriately cared for by the university's own therapeutic or remedial services than by punitive disciplinary measures.95 Without recourse to vague rules, these well-established prerogatives furnish the university with sufficient flexibility to cope with the second type of student.

A third type of situation requiring flexibility involves the student whose deliberate intention it is to frustrate university policy embodied in its disciplinary regulations by carefully confining himself to offensive behavior that the university has neglected to include in its precise code. ${ }^{96}$ The vague standards of "ungentlemanly behavior" that are cur-

93. An unconventional attempt to review state university admissions policies was made in Lesser v. Board of Educ., 35 Misc. 2d 896, 232 N.Y.S.2d 151 (Sup. Ct. 1962), which granted relief to a high school student who had been denied college admission as a non-tuition paying student, on the theory that the university's failure to consider the fact that he had pursued an unusually difficult course of study in high school constituted a reviewable administrative error. The court directed reconsideration of petitioner's application and an upward adjustment of his grades. The Appellate Division reversed, 18 App. Div. 2d 388, 239 N.Y.S.2d 776 (1963), repeating the familiar holding that courts may not interfere with administrative decisions of state agencies in the absence of a clear abuse of discretion.

94. See note 81 supra.

95. On the relationship of therapeutic services to discipline for misconduct, see generally Esteban v. Central Mo. State College, 290 F. Supp. 622, 629 (WD. MIo. 1968), af'd, 415 F.2d 1077 (8th Cir. 1969), cert. denied, 398 U.S. 965 (1970); Linde, Campus Law: Berlscley Fiewed from Eugene, 54 CALIF. L. REv. 40, 49 (1966); Van Alstyne, Judicial Trend Toutard Student Academic Freedom, 20 U. FLA. L. REv. 290, 297 (1968); Note, Privale Government on the Campus-Judicial Review of University Expulsions, 62 YaLE L.J. 1362, 1407 (1963).

96. It has been suggested that just such individuals make catchall misconduct regulations necessary. Note, Uncertainty in College Disciplinary Regulations, 29 OHı Sr. L.J. 1023, 1034 (1968). Dissenting in Winters v. New York, 333 U.S. 507, 525, 533 (1948), Justice Frankfurter must have been contemplating much the same lind of person when he warned that "[i]f a law is framed with narrow particularity, too easy opportunities are afforded to nullify the purposes of the legislation ... Legislation must also avoid so tight a phrasing as to leave the area for evasion ampler than that which is condemned." 
rently in use enable the university to reach such an individual. But to suggest that precise rules would prevent the university from disciplin. ing him would be mistaken. Although the university might be tempted to bend its precise disciplinary provisions to reach the individual whose course of conduct may violate the spirit, though not the letter, of the law, this practice would do violence to the very values upon which the vagueness doctrine is predicated. The more principled, though less expedient, response to this rare individual would be for the university to amend its code so that such misbehavior will not again go unpunished. The fact that a clearly drawn code may assist those few students who are not well-intentioned does not justify a refusal to seek precision. ${ }^{07}$

This analysis indicates that precious little flexibility is at stake despite intimations by the courts that precise rules would divert the academic community from its proper pursuits and deprive administrators of latitude in dealing with difficult students. Moreover, emphasis on the difficult cases should not obscure the overriding fact that, because they focus their deterrent effect on specific forms of anti-social behavior, precise rules may actually help the university achieve its disciplinary goals.

\section{B. Substitutes for the Vagueness Doctrine}

None of the other possible reasons for the courts' refusal to apply the vagueness doctrine is more persuasive than those analyzed above. Certain of the cases seem to suggest that courts do not attach significance to precision when they are satisfied that the student's other constitutional rights have not been violated. At least one court discounted a claim of vagueness when the student had enjoyed the hearing mandated by Dixon..$^{88}$ As noted, other courts seem to require precision only of regulations which on their face govern First Amencl-

97. According to Note, Uncertainty in College Disciplinary Regtulations, 29 Onto Sr. L.J. 1023, 1036 (1968):

General terminology has admitted conveniences to administrators, but its use reflects an obsessive fear that a single student may go unpunished for an unforeseen and un. acceptable departure from the norms of campus behavior.

Linde suggests that an occasional escape from punishment is a commonplace cost of our judicial system generally. Linde, Campus Law: Berkeley Viewed From Eugene, 54 GAL11. L. REV، 40, 63 (1966).

98. The court in Dunmar v. Ailes, 348 F.2d 51, 55 (D.C. Cir. 1965), aff'g 290 F. Supp. 87 (D.D.C. 1964), reasoned:

Appellant's second contention is in effect that the Cadet Honor Code . . . is void for vagueness. ... Appellant's conduct was first found to violate this code by the Cadet Honor Committee, a student body entrusted with such matters, second by a board of officers before which Appellant had a full trial-type hearing, third by a reviewing board, fourth by the Superintendent of the Academy. ... We are in no position to find too vague the code thus found applicable. 
ment rights. ${ }^{99}$ However, the assumption that other constitutional principles afford the university student as much protection as he needs is false because vagueness raises unique problems which only precision can remedy.

A belief that Dixon renders the vagueness doctrine unnecessary on campus is not warranted because no procedural safeguards-for example, the right to a hearing, advice of counsel and cross-examinationwill fully protect a student whom the university prosecutes under vague regulations. By the time of such a hearing, vague regulations might already have denied the student adequate notice that his conduct was punishable, permitted enforcement officials to treat him in an arbitrary or discriminatory manner, and exerted a "chilling effect" on his and others' constitutionally protected freedoms. And if the student should appeal an adverse determination, the vague rule under which he was prosecuted may continue to prejudice him. Its ambiguity may deprive the reviewing court of a clear statement of the university's perceived interest in proscribing his behavior, without which the court could not assess the constitutionality of the rule or the fairness of its application to his case.

Equally unfounded is a belief that the First Amendment is functionally equivalent to the vagueness doctrine. First, freedoms beyond those protected by the Amendment may be chilled. Second, reliance on the First Amendment overlooks the other evils of vagueness-insufficient notice, excessive administrative discretion and inadequate judicial review. In holding that the vagueness doctrine has added importance in First Amendment cases, ${ }^{100}$ the Court must be implying that it has basic importance even in areas where the First Amendment does not apply.

\section{G. Limitations on the Vagueness Doctrine}

Courts seldom apply any doctrine mechanically. They tend instead to develop exceptions when use of the doctrine would seem inappro-

99. As previously indicated, pp. 1264-65 and notes 21-24 supra, with the exception of Soglin v. Kauffman, 418 F.2d 163 (7th Cir. 1969), aff'g 295 F. Supp. 978 (W.D. Wis. 1968), the cases that have utilized the vagueness doctrine to invalidate university rules have ali directly involved the First Amendment. This may indicate a judicial assumption cither that First Amendment protection fully prevents the evils of vagueness or that no individual rights except those subsumed by the First Amendment are worthy of protection from the vices of vagueness. Both assumptions, as this Note will show, are false. There is language in Goldberg v. Regents of Univ. of Cal., $248 \mathrm{Cal}$. App. 2d 867, 881, $57 \mathrm{Cal}$. Rptr. 463, 473 (1967) suggesting that once disciplinary action has been found to be "a proper exercise of [the university's] inherent general powers to maintain order on the campus," a court need not consider the specific claim by a student that the rule under which he was punished suffered from unconstitutional vagueness. This seems no more defensible than igmoring such a claim on the grounds that Dixon or First Amendment protections are availible to the student.

100. See cases cited note $\mathbf{3 1}$ supra. 
priate in a given situation. Thus, they may waive its application when the problems that the doctrine is designed to solve are not present or, if present, would be difficult or impossible to eliminate. However, consideration of the factors that have dissuaded courts from invalidating vague standards in contexts other than university discipline does not explain the courts' failure to apply the vagueness doctrine on campus. ${ }^{101}$

First, the courts have relaxed the requirement of precision when greater specificity seems unattainable. ${ }^{102}$ On occasion universities ap. pear to have convinced courts that they could not anticipate all modes of anti-social behavior. ${ }^{103}$ That student misconduct takes diverse and unpredictable forms is undeniable. But, in exempting university officials from the vagueness doctrine the courts have relieved them of any obligation to seek precision at all. This is inappropriate, for experience indicates that a relatively high degree of precision can be attained. The University of Oregon recently replaced its vague misconduct provisions with a series of relatively precise rules predicated on specified interests of the university. ${ }^{104}$ One observer has commented, on the basis of the Oregon experience, that:

It is a fiction that no university code can adequately inform students of all rules duly adopted that carry disciplinary sanctions ... without including some very general catchall rules of good conduct. . . . ${ }^{105}$

Some courts fear that to particularize proscribed conduct might even invite misbehavior by some students. Thus, one court has exempted a state university from the vagueness doctrine on the ground that "detailed codes of prohibited student conduct are provocative."103 In view of the ease with which a campus code may be amended, however, there will be few who can persist in frustrating the university. ${ }^{107}$

Second, as noted earlier, ${ }^{108}$ the courts have held that a standard of

101. Two factors that have led courts to tolerate vagueness-the fact that sanctions are not severe and the fear that a requirement of precision will unduly interfere with ad. ministrative flexibility-are discussed at $\mathrm{pp}$. 1271.73 and $\mathrm{pp}$. 1280.84 supra, respectively.

102. See, e.g., United States v. Petrillo, 332 U.S. 1, 7 (1947); Sproles v, Binforl, 286 U.S. 374, 393 (1932); United States v. Alford, 274 U.S. 264 (1927); Miller v. Strah1, 239 U.S. 426, 434 (1915); Baltimore \& O. R.R. V. ICC 221 U.S. 612620 (1911); Note, The Void-For-Vagtueness Doctrine in the Supreme Court, 109 U. PA. L. REv. 67, 95 (1960).

103. See note 96 supra.

104. Linde, Campus Law: Berkeley Viewed from Eugene, 54 CAuIf. L. REv, 40 (1966).

105. Id. at 63 .

106. General Order on Judicial Standards of Procedure and Substance in Revicw of Student Discipline in Tax Supported Institutions of Higher Education, 45 F.R.D. 133, 116. 47 (W.D. Mo. 1968).

107. See pp. 1283.84 supra.

108. See note 63 stipra. 
conduct which is vague on its face may be constitutionally acceptable if a precise meaning can be imputed to it from some external source. For example, "constructive notice," from either official warnings ${ }^{103}$ or widely recognized campus standards, 1110 has on occasion managed to save an otherwise vague university rule. ${ }^{111}$ Presumably, constructive notice would also enable a revierving court to assess the constitutionality of a campus rule and the fairness of its application. But though official warnings or well-defined campus standards may eliminate the problems of insufficient notice and inadequate judicial review, the other evils remain. Vague rules, even when supplemented with notice, confer upon an enforcement official unlimited freedom to proscribe whatever he pleases. Nor is the "chilling effect" mitigated by constructive notice.112 Thus, even when there is viable constructive notice, the vagueness doctrine retains unique utility.

\section{Implications of the Vagueness Doctrine on Campus}

This Note has suggested that many university regulations exhibit the elements necessary for application of the vagueness doctrine, that the special nature of the university heightens the need for that doctrine and that the arguments frequently advanced by the courts for putting it aside are unpersuasive. Thus, courts ought to apply the vagueness doctrine to disciplinary codes.

109. In Cornette v. Aldridge, 408 S.TW.2d 935, 941 (Tex. Civ. App. 1960) the court noted that petitioner had been warned repeatedly that the precise conduct for which he was eventually disciplined would lead to punishment. Two prior suspensions of a student for similar conduct were deemed to constitute notice in Steier $v$. New York State Educ. Comm'r, 271 F.2d 13, 20 (2d Cir. 1959), cert. denied, 361 U.S. 966 (1960). See also Esteban v. Central Mo. State College, 415 F.2d 1077, 1088 (8th Cir. 1969), af'g 290 F. Supp. 622 (W.D. Mo. 1968), cert. denied, 398 U.S. 965 (1970); O'Leary v. Commonwealth, 441 S.XV.2d 150,157 (Ky.), cert. denied, 396 U.S. 40 (1969). Nor could a student who courts punishment by intentional misconduct, perhaps to dramatize an issue or to test the constitutionality of a regulation, convincingly contend that he lacked fair warning. Such, at least, is the sug. gestion in Buttny v. Smiley, 281 F. Supp. 280, 285 (D. Colo. 1968).

110. The court in Goldberg v. Regents of Univ. of Calif., $248 \mathrm{Cal}$. App. 2d 867, $57 \mathrm{Cal}$. Rptr. 463 (1967), assumed that the students were acquainted with campus norms of social behavior and would read them into the university's general misconduct rules.

111. "Constructive notice" has also been derived from the common law, judicial or ad. ministrative "glosses" of statutory language, and from ordinary cxperience and usage. See generally United States v. Ragen, 314 U.S. 513, 524 (1942); Sproles v. Binford, 286 U.S. 374, 393 (1932); Hygrade Provision Co. v. Sherman, 266 U.S. 497, 502 (1925); Omnechevarrin v. Idaho, 246 U.S. 343, 348 (1918); Fox v. Washington, 236 U.S. 273, 277 (1915); Nash v. United States, 229 U.S. 373, 376-78 (1913); Waters-Pierce Oil Co. v. Texas (No. 1), 212 U.S. 86, 103 (1905); Note, The Void-For-Vagueness Doctrine in the Suprcme Court, $109 \mathrm{U}$. PA. I. REV. $67,84(1960)$.

112. Although the student who is found to hare violnted a vgue rule has not been chilled with respect to the conduct for which he is punished, other students may have been. Furthermore, vague rules may well have discouraged him and others from participating in a host of activities in which they might have engaged but for their fear of punishment. 
One implication of a judicially-imposed requirement of precision is that a university's sense of community may be impaired. ${ }^{113}$ By becoming a partisan in campus disputes, the court may foster a litigious spirit among students and embitter the academic community. ${ }^{114}$ Such predictions, however, usually stem from the imposition of specific requirements by the courts rather than from judicial intervention per se. Such was the argument against the introduction of trial-type hearings before and after the Dixon case. ${ }^{115}$ There is little doubt that campus unrest, and with it a growing assertiveness by students of their constitutional rights, has strained relations within the university. But, since this development is part of a larger social and political upheaval, it is unlikely that Dixon and the cases which followed it were responsible for undermining goodwill and understanding on campus. ${ }^{110}$ Rather than being a cause of assertiveness and unrest, Dixon was more probably its result.

Commentators continue, nonetheless, to disagree over whether and to what extent a full blown judicial model will subvert the spirit of common purpose essential to higher education. ${ }^{117}$ The effects of each step in the direction of greater formality of university discipline have

113. Courts have expressed concern that such requirements would be "detrimental to the educational atmosphere and functions of a university." Goldberg v. Regents of Univ. of Cal., 248 Cal. App. 2d 867, 881, 57 Cal. Rptr. 463, 473 (1967). See also Knight v. Statc Bd. of Educ., 200 F. Supp. 174, 179 (M.D. Tenn. 1961).

114. The dissenting opinion in Dixon lamented that "[e]very attempt at discipline would probably lead to a cause célebbre, in connection with which federal functionarics would be rushed in to investigate whether a federal law had been violated." $294 \mathrm{~F} .2 \mathrm{~d} 150$, 165 (5th Cir. 1961) (Cameron, J. dissenting), rev'g 186 F. Supp. 945 (M.D. Ala. 1960), cert. denied, 368 U.S. 930 (1961). See generally Beaney, Students, Higher Education and the Law, 45 Denver L.J. 511, 515-17 (1968); Carrington, Civilizing University Discipline, 69 Mrch. L. Rev. 393, 405 (1971); Perkins, The University and Due Process, 62 AM. IUURARX Ass'N Buld. 977, 978-79, 981 (1968); But see Byse, The University and Due Process: $A$ Some. what Different View, 54 AM. Ass' N OF U. Prof. BuLr. 143, 146 (1968).

115. Objection to judicially-imposed formalities in university disciplinary procedures permeated a number of cases long pre-dating Dixon. See, e.g., Tanton v. McKenney, 226 Mich. 245, 197 N.W. 510 (1924); State ex rel. Grain v. Hamilton, 42 Mo. App. 24 (1890); State ex rel. Ingersoll v. Clapp, 81 Mont. 200, 215, 263 P. 433, 437, appeal dismissed, 278 U.S. 661 (1928); Barker v. Bryn Mawr College, 278 Pa. 121, 122 A. 220 (1923). Xet not all the older cases so feared the introduction of trial type procedures. See, e.g., Commonwealth ex rel. Hill v. McCauley, 3 Pa. Co. Ct. R. 77 (1887).

More recently, reluctance to require formal hearings on campus has been expressed in the following cases: Dixon v. Alabama State Bd, of Educ., 294 F.2d 150, 159 (5th Gir, 1961) (Cameron, J., dissenting), rev'g 186 F. Supp. 945 (M.D. Ala. 1960), cert. denicd, 368 U.S. 930 (1961); Greene v. Howard Univ., 271 F. Supp. 609, 615 (D.D.C. 1967); Dehaan v. Brat1. deis Univ., 150 F. Supp. 626 (D. Mass. 1957); Goldberg v. Regents of Univ. of Cal., 248 Cal. App. $2 \mathrm{~d}$ 867, 880-81, 57 Cal. Rptr. 463, 472-73 (1967). See especially, Carrington, Civili. zing University Discipline, 69 Mrat. L. REv, 393 (1971).

116. Among the many discussions of the changing student-university relationship seo Van Alstyne, The Judicial Trend Toward Student Academic Freedom, 20 U. FLA, L. RuV. 290 (1968); Wright, The Constitution on the Campus, 22 VAND. L. REv. 1027 (1969); Sym. posium, Student Rights and Campus Rules, 54 CALIF. L. REv. 1 (1969); Conference, Legal Aspects of Student-Institutional Relationships, 45 DENvER L.J. 497 (1968); Note, Devclap. ments in the Law-Academic Freedom, 81 HARv. L. REv. 1045 (1968).

117. See notes 113-14 supra. 
been hotly debated. ${ }^{118}$ Presumably each additional step has been and will be taken only after a careful consideration of the totality of its effects on the university including that community's sense of purpose. Apparently Dixon reflects a judgment that the benefits of a hearing prior to student dismissal outweigh its costs to the university. In any event, precision in rule-making does not raise for a community the same problems as an adversarial hearing. Precise rules do not entail conflict in the sense that formal hearings, almost by definition, seem to. In clarifying university policy, in acquainting students with their rights and duties, and in eliminating the other evils of vagueness, precision is as supportive of a familial as of an adversarial approach to discipline. In fact, imprecise rules seem to have their own adverse effects upon an academic community.119 Thus, in recent campus crises, vague rules exacerbated rather than alleviated the already volatile campus atmosphere. Post mortems on those controversies identified imprecise rules as a source of confusion and rancor. ${ }^{120}$ In fact, a rule-making process in which students, faculty and administrators came together to exchange and to reconcile their diverse views, might have fostered the mutual understanding essential to a peaceful resolution of campus conflict.121

The introduction of the vagueness doctrine on campus has other implications. The vague rules that have been in operation have afforded the university considerable latitude in dealing with an individual's misconduct, leaving administrators free to establish a pattern of discipline without revealing its precise purpose, to depart from that pattern at will, or to discipline students on an entirely ad hoc basis. By enabling administrators to establish a disciplinary policy without articulating it, vague rules have made them less accountable to public pressure.

When, under compulsion of the vagueness doctrine, however, the university begins to define formally and for the first time the rights and

118. Concerning the Dixon decision see notes and comments in 35 TEurLE L.Q. 437 (1962); 15 VAND. L. REv. 1005 (1962); 75 HARv. L. REv. 1499 (1962); 38 N.D. L. REV. 346 (1962); 60 Mrch. L. REv. 499 (1962); 50 Geo. L.J. 314 (1961); 14 AlA. L. REv. 126 (1961).

119. Wright, The Constitution on the Campus, 20 VAND. L REv. 1027, 1063 (1969);

Note, Uncertainty in College Disciplinary Regulations 29 Omo Sr. L.J. 1023, 1036 (1963).

120. Sherry, Governance of the University: Rules, Rights and Responsibilities, 54 Culn. L. Rev. 23, 37 (1966) (Berkeley): Cox Conanssion, CRisis at Coluarou: Reporr of tile Fact-Finding Comarission Appolnted to Investigate the Disturbances at Colummia UitVERSITY IN APRI AND MIAY, 1968, (the Cox Commission Report) at 70 (1968).

121. Professor Wright, commenting in The Constitution on the Campus, 22 VANo. $L$ REv. 1027, 1087 (1969), emphasizes the community-building potentinl of rulc-mal.ing:

Needed changes to meet constitutional criteria can, of course, be made by administrative or regential fiat, but to do so is to overlook the obvious opportunity that this task presents to deepen the sense that there is an academic community, of which students, faculty, administrators, and regents are all part, by permitting all of the elements in the community to participate in the process. 
obligations of its students, interested groups will be presented with an unprecedented opportunity to influence disciplinary policy. ${ }^{122}$ Of course, the advent of precise rules will enlarge the scope of student freedom on all campuses by eliminating the possibility of entrapment, of arbitrary and discriminatory treatment, and of the "chilling effect." But these interested groups-alumni of the university, parents of its students and public figures both national and local-can be expected to exert pressure on the draftsmen of disciplinary regulations either to enlarge or to reduce the scope of student rights. If they feel that the university is too restrictive, or more likely, too permissive, in its disciplinary policy, they may withdraw their political and financial support without which the university cannot survive. ${ }^{123}$ Since state universities rely so heavily on such support, they are particularly vulnerable to these pressures. ${ }^{124}$ It may therefore seem appropriate for them to make public favor a dominant consideration behind disciplinary policy. Depending upon the views of university officials and their ability to resist external influences, political pressures will in any event determine the substance of student rights.

The code that results from this interplay may on certain campuses free students to engage in a wider range of activities. But preliminary indications suggest that the opposite may occur at many if not most universities. For example, the University of Arizona, which voluntarily undertook to rewrite its disciplinary code in more precise terms, far

122. One recent decision attributed the dilemma of the state university official at least in part to anticipated reactions of legislators:

The leaders of great universities are frequently required to make agonizing, hard de. cisions which may well affect the very existence of the university as a free institution. On one side the university president must consider what the legislature may think; on the other, he must consider what the militant students may think.

Lieberman v. Marshall, 236 So. 2d 120, 123 (Fla. 1970). Commentators have also noted the vulnerability of universities to external pressures. See, e.g., Note, Uncertainty in College Disciplinary Regulations, 29 OHIO ST. L.J. 1023, 1034 (1968):

The dependence of the state institution and its administrators upon the legislature and governor for funds and employment creates political pressures upon the adminis. tration. The politician who responds to public demands will exert pressurc upon administrators to discipline students whose activities are offensive to the public. The existence of general conduct regulations often permits such pressures to be cffectively applied, with the results that students with unpopular views are dismissed from college for expressing those views.

See also Carrington, Civilizing University Discipline, 69 Mrch. L. REv. 398, 406 (1971); Kenniston \& Lerner, The Unholy Alliance Against the Campus, N.Y. Times, Nov. 8, 1970, (Magazine) at 28; Wright, The Constitution on the Campus, 22 VAND. L. REv. 1027, 1084 (1969).

123. See note 122 supra.

124. It has been suggested, however, that precise rules actually give the university ad. ministrator greater independence than he would have under vague rules, because they insulate from pressure to punish conduct which has not been specifically proscribed. Note, Uncertainty in College Disciplinary Regulations, 29 OHIO ST. L.J. 1023, 1034 (1968). 
from becoming more liberal, drastically restricted the scope of student freedom. ${ }^{125}$

If this trend continues, the courts can anticipate a rising volume of challenges on substantive grounds to the validity of particular disciplinary regulations. ${ }^{126}$ With familiar constitutional tests they can, as they have done elsewhere, seek to accommodate on campus the often divergent interests of the individual and those who govern him.

125. Crackdown on Campus, NewsweE, Dec. 7, 1970, at 96. The Arizona Code includes the following prohibitions:

Distribution or wearing of arm bands, buttons or signs or the carrying or posting of signs, banners or posters having an obscene or controversial significance in a manner which distracts and substantially interferes with the normal activities or appropriate discipline of the university .....

Participation in any crowd, assembly, parade, demonstration, sit-in or similar event which substantially interferes with or disrupts the normal activities of the university or any university sponsored or supervised function.

Publish or threaten to publish any malicious falschood, expresed by uriting, printing or pictures, which tends to impeach the honesty, integrity or reputation of any member of the University Community or which tends to bring such person into disrepute, contempt or ridicule.

126. For some discussion of the substantive limits of university rulc-making see Carrington, Civilizing University Discipline, 69 Mich. L. REv. 393, 400 (1971). Nole, The Emerging Law of Students' Rights, 23 ARK. L. REv. 619, 628-33 (1970); Notc, Privale Government on the Campus-Judicial Review of University Expulsions, 72 YALE L.J. 1362, 1395-1403 (1963). 